Article

\title{
Roberto Lugo: Critical Discussions of Hip-Hop, Ceramics, and Visual Culture
}

\author{
Heather Kaplan $(\mathbb{D}$ \\ Department of Art, The University of Texas at El Paso, El Paso, TX 79968, USA; hgkaplan@utep.edu
}

Received: 30 September 2018; Accepted: 6 December 2018; Published: 10 December 2018

check for

\begin{abstract}
This paper looks at the creative work of "ghetto potter" Roberto Lugo. Through the examination of his various forms of art-making, various discussions regarding the intersections of ceramics, hip-hop, and visual culture are explored. Through these intersections, issues related to access and equity are explored. This paper explores topics and issues important to visual culture and art education.
\end{abstract}

Keywords: hip-hop; ceramics; visual culture; Roberto Lugo; identity politics; porcelain

\section{Introduction}

This paper looks to the work of contemporary ceramic artist Roberto Lugo as a way to understand and theorize on the connection between hip-hop and visual arts and visual culture. Lugo, an artist of many forms, including graffiti art, spoken word poetry, or rap, and the form for which he has received the most acclaim, contemporary pottery, is the embodiment or practice of hip-hop's intersection with the visual. This paper explores how his practices are situated within the vernacular of hip-hop, how the work he creates functions similarly to the politics of rap and hip-hop in that it creates a space for identities and narratives that counter white cultural hegemony, and how his work can be used to unpack the way that form and ideas intersect in order to explore the connections between meaning, message, and material in art education.

Lugo's work has created a forum for black social consciousness and called into question practices and privileges inherent and specific to the field of ceramics. Because of this, his work speaks to larger visual culture and social justice concerns of representation, visuality, and power, laid bare through reimagining and reclaiming (cultural) space. Lugo does this through a "hip-hop aesthetic", meaning both cultural productions and civic, political, and artistic practices that originate from and contribute to contemporary notions of urban black culture and politics. More specifically, Lugo's hip-hop aesthetic speaks to black consciousness raising, questioning white visual hegemony, visuality, and visual culture.

Roberto Lugo explains that his practice encompasses a variety of methods, including being a "potter, activist, culture-maker, rapper, poet, and educator;" (Lugo, personal communication July 2018), yet his rising star is specifically in the ceramics world. This very year, 2018, Ceramics Art Network, Ceramics Monthly, and Pottery Making Illustrated all named him the ceramic artist of the year. In 2015, Lugo was named a National Council for Education in the Ceramic Arts (NCECA) Emerging Artist of the Year. So, while Lugo's work takes many forms, it seems that the world of ceramics is claiming much of his work as their own. For many in the ceramics field, this is seen as a windfall, especially for a field that has been criticized for its white monoculture and the hierarchy that it historically placed on white porcelain from Europe and Asia.

\section{How Roberto Lugo's Pottery Questions the Practice of Privileging White Bodies}

Historically, great value has been placed on porcelain ceramics. This is largely due not only to the material's qualities (being both highly refined and able to create thin, delicate wares that are also 
resiliently strong) but also because of its initial scarcity (De Waal 2016). Porcelain originated from Jingdezhen, China and was initially only available through trade with the East. From the 13th century until the beginning of the 18th century, porcelain was an expensive import that was not producible in Europe. Even after it was able to be manufactured in Germany and England, porcelain remained "for the refined, for the ruling class, with all of its power and privilege" (La Force 2015). In ceramics, metaphors of clay bodies and the body prevail, and it is no mistake that porcelaneous and white bodies are often fetishized for their elite refinement produced not only by their comparatively smaller and finer particle size but for their relationship to white bodies, culture, and general qualities of whiteness. Where whiteness refers not only to a sense of purity, cleanliness, and sterility, it also refers to a cultural structure of power and privilege often invisible and described by a lack rather than as a set of visible characteristics (Lopez 2005). In the field of ceramics, whiteness implies a lack of voices from people from diverse and different cultural heritage; typically, ceramics draws its historical roots from Asia and Europe (rather than from indigenous people of the Americas, Africa, or Oceania) (Gupta Wiggers 2013) and practitioners are, more often than not, of European or Asian heritage.

As the son of Puerto Rican immigrants, Lugo grew up "in a poverty blighted neighborhood of Philadelphia" (Brown 2017, p. 54). He proudly declares that his lineage has African roots (Brown 2017, p. 56) and that he identifies as and with people of color. While many may see the inclusion of underrepresented minorities like Lugo in the pottery tradition as progress, what is all the more exciting is that the work, which is about the clash of two disparate cultures, has been widely embraced by the field. Lugo is not a minority artist in name only; his work speaks to forms and ideas that wrestle between minority and mainstream culture, low and high culture, popular and niche markets, contemporary urbanity and historical gentility, blackness and whiteness, and hip-hop and pottery.

Lugo creates works that often employ familiar European and Asian pottery forms like the urn, teapot, and tea bowl that are ornately decorated, often using gold luster and china paint. The works involve the layering of ornamental pattern like those found in other craft and industrialized art forms, including fabrics and printed wallpapers, and are employed in a style similar to Vienna Secessionist Gustav Klimt. These patterns fill the entire form, save for the spaces that Lugo leaves for equally detailed rendered portraits of persons of historical, political, cultural, or social import. Often, Lugo juxtaposes two like or unlike figures to coax the viewer into understandings precipitated through their connections and comparisons. For instance, the work The Expulsion of Colin Kaepernick and John Brown, 2017 (Figures 1 and 2) has China painted images of both the former San Francisco 49ers quarterback, and now free agent Colin Kaepernick and the American abolitionist John Brown. Lugo places the portraits of Kaepernick and Brown on opposite sides of the same porcelain urn as if two sides of the same coin. This helps the viewer to make connections between the revolutionary actions of John Brown, who led a raid on the arsenal at Harpers Ferry, West Virginia on 16 October 1859 in the hopes of arming slaves and starting a slave rebellion (Bisson 2009), and the contemporary and controversial actions of Colin Kaepernick, who took a knee during the National Anthem in order to rally others, ignite conversation, and bring further attention to the Black Lives Matter movement (Gregory 2017), a movement that questions white power structures and latent cultural beliefs that ultimately lead to the death and brutalization of African Americans at the hands of law enforcement. 


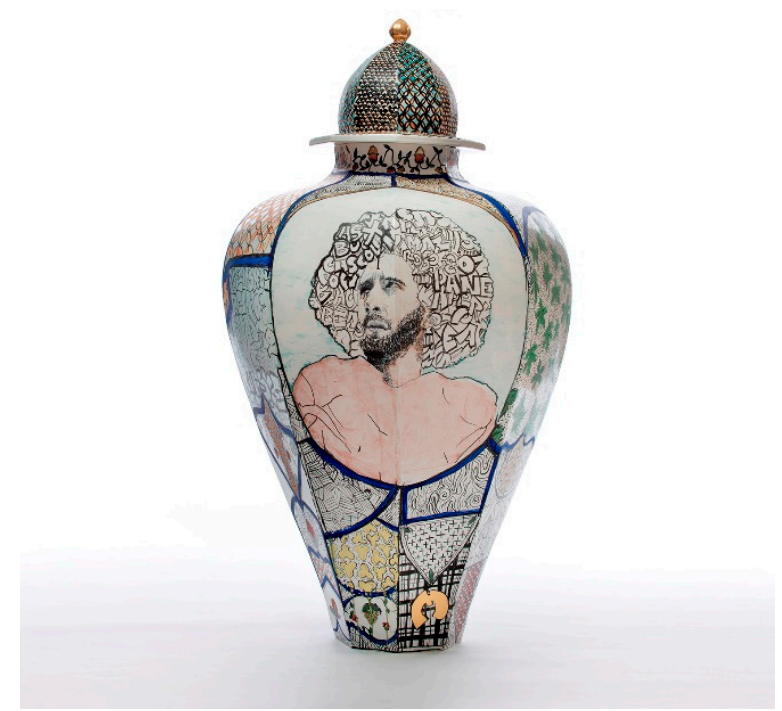

Figure 1. The Expulsion of Colin Kaepernick and John Brown, 2017, Porcelain, china paint, luster, $47 \times 24$ $\times 24$ in. Image by KeneK Photography, courtesy of Wexler Gallery.

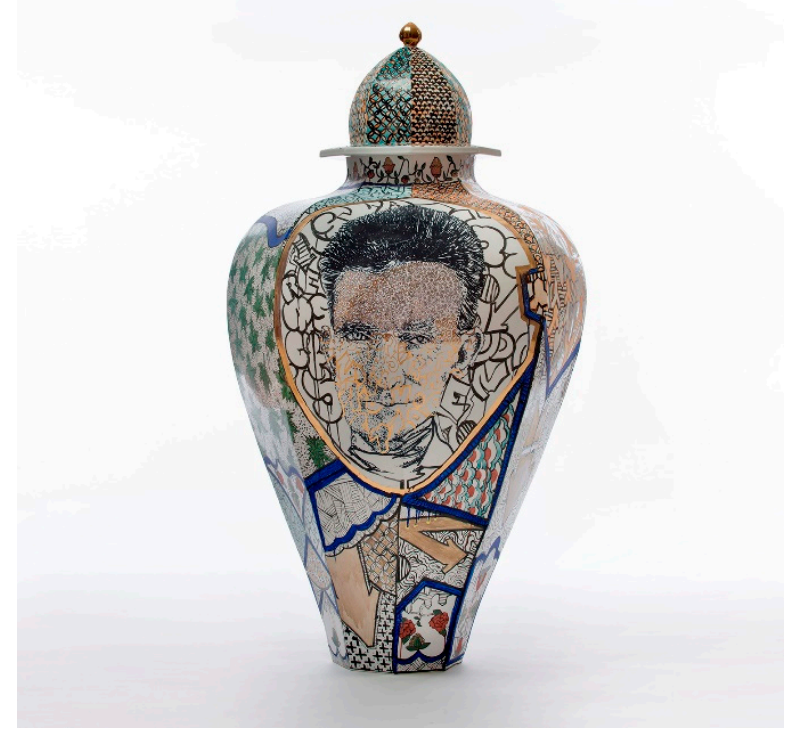

Figure 2. The Expulsion of Colin Kaepernick and John Brown, 2017, Porcelain, china paint, luster, $47 \times 24$ $\times 24$ in. Image by KeneK Photography, courtesy of Wexler Gallery.

In western art history and institutions, ceramics is a smaller field than other "fine art" fields, like painting and sculpture. Therefore, fewer people have studied the field (Brown 2006, p. 38), even fewer are familiar with contemporary ceramics, and fewer still with contemporary pottery and the people and practices involved in it. This can lead to isolated or niche cultural practices. On the other hand, hip-hop and rap, though originally minority cultural forms, are much more widely dispersed within the larger visual and cultural realms. This is possibly in part because of the very form, popular music, which constitutes hip-hop and rap (the ceramic medium and the delicate pots and ceramic sculptures it produces are more difficult to transport or transmit to a mass audience). Unlike traditional ceramics, hip-hop's ease of transmission and the ubiquity of popular music imply that hip-hop is received by and possibly practiced by larger masses of people; it is truly part of popular culture.

By incorporating both minority and popular visual cultural practices in his pottery, Lugo's work seems to be the breath of fresh air that might enliven an insular art form, contemporary pottery, that only a few collectors and practitioners regard as relevant to contemporary culture (Clark 2007, 
p. 103). His remixing and mashing of disparate cultures (hip-hop popular aesthetics, art and crafts patterning, and white porcelain pottery) opens avenues for new ideas and practices in ceramics, while it creates spaces for minority voices and practices in art forms like ceramics that have been historically white and Asian expressions of culture. Lugo's inclusion in the world of pottery stands not only to create new authorship within the field, but his remixing of culture and his activism stands to re-enliven the field through the creation of new vernacular, new viewership, and new modes of exhibition.

\section{Practicing Hip-Hop through Pottery}

Lugo, who calls himself a "ghetto potter", which he defines positively as resourceful rather than as a derogatory term (Lugo n.d.), claims the term hip-hop when referring to his work. He states, "I like to think of myself as a hip-hop artist through pottery." (R. Lugo, personal communication, 6 June 2018) Lugo's recent work makes direct reference to hip-hop culture through visual representations of rap artists and of athletic shoes. In the work titled Method Man and Jimi Hendrix, 2018 (Figures 3 and 4), Lugo depicts the musical artists named in the title on opposite sides of a lidded jar/urn. This work, along with others like A Century of Black Music, 2018 (Figures 5 and 6), draws historical and cultural connections between black musical accomplishments over time and more contemporary and controversial work of hip-hop artists. Additionally, works like Stunting: Pump 1, 2018 (Figures 7 and 8) and Stunting: Clean Joint, 2018 (Figures 9 and 10) use the visual vernacular of athletic or basketball shoes as a clear reference to hip-hop attire. While both works reference athletic footwear, the first clearly references the athletic shoe Reebok Pump through a ceramic representation of the familiar orange plastic pump, replete with the letters "PUMP" and with the bolder, brighter coloring of the Reebok brand. The second employs easily recognizable leather treatments, such as white leather stitching and the regimented patterning of dots, universal to white leather athletic shoes. While the titles may refer to ceramic processes of making a clean joint between two connections in clay, pumping clay slurry for slip casting, or using an air pump for gas kiln burners, the titles clearly refer to hip-hop vernacular: Stunting is urban slang for "showing off". Due to the price of finer athletic shoes, those who wore them often did not do so in order to play sports but did so as a sign of status and of being part of the culture (Stapleton et al. 2005). This point does not appear to be lost to Lugo, who emphasizes it through the use of gold lusters, a lavish finishing application and sign of expense.

Figure 3. Method Man and Jimi Hendrix, 2018, Earthenware and china paint, $13 \times 13 \times 26$ in. Image by KeneK Photography, courtesy of Wexler Gallery. 


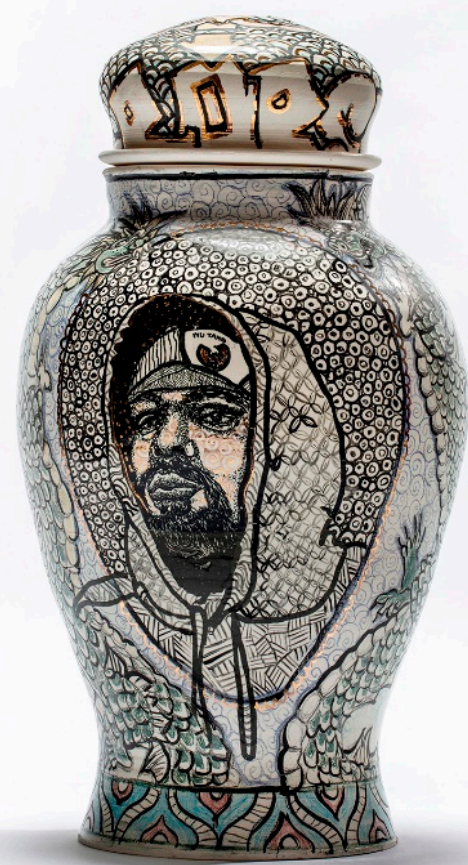

Figure 4. Method Man and Jimi Hendrix, 2018, Earthenware and china paint, $13 \times 13 \times 26$ in. Image by KeneK Photography, courtesy of Wexler Gallery.

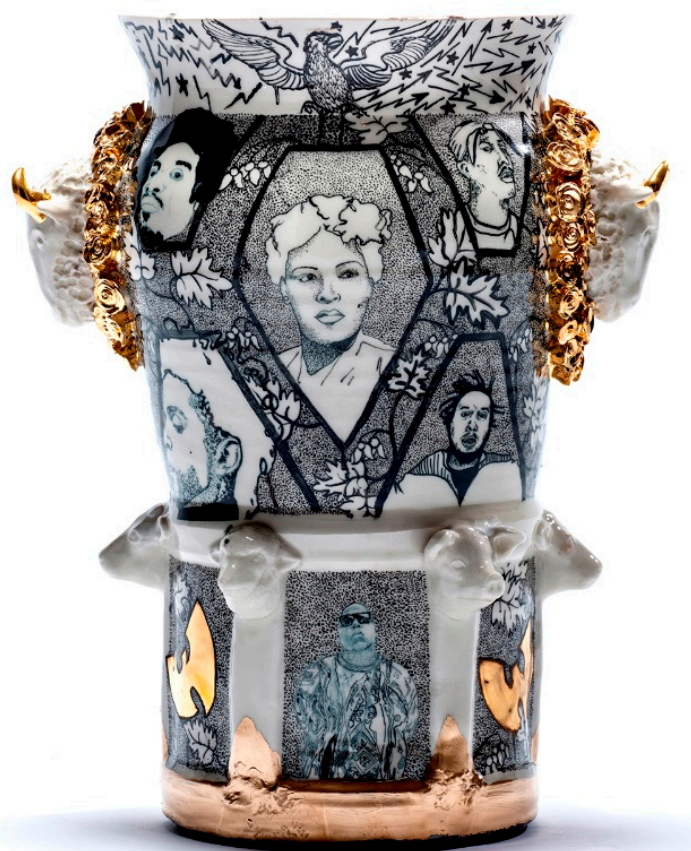

Figure 5. A Century of Black Music, 2018, Porcelain and china paint, $13 \times 9 \times 16$ in. Image by KeneK Photography, courtesy of Wexler Gallery. 


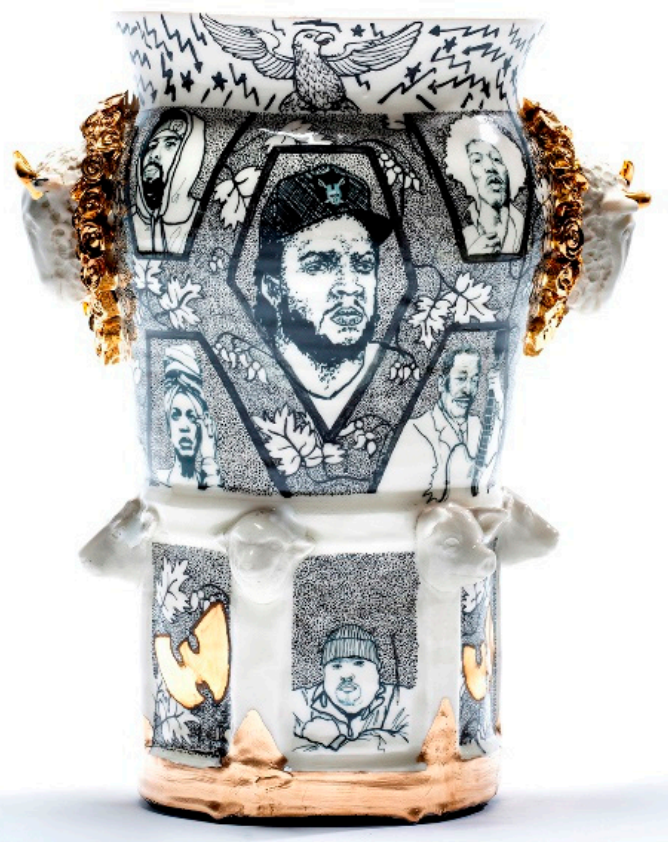

Figure 6. A Century of Black Music, 2018, Porcelain and china paint, $13 \times 9 \times 16$ in. Image by KeneK Photography, courtesy of Wexler Gallery.

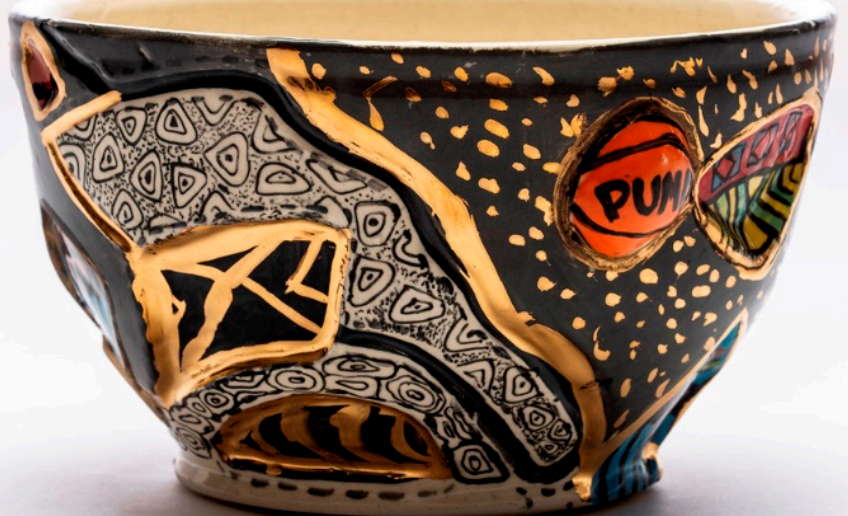

Figure 7. Stunting: Pump I, 2018, Porcelain, china paint, luster, $5 \times 10 \times 10$ in. Image by KeneK Photography, courtesy of Wexler Gallery. 
Figure 8. Stunting: Pump I, 2018, Porcelain, china paint, luster, $5 \times 10 \times 10$ in. Image by KeneK Photography, courtesy of Wexler Gallery.

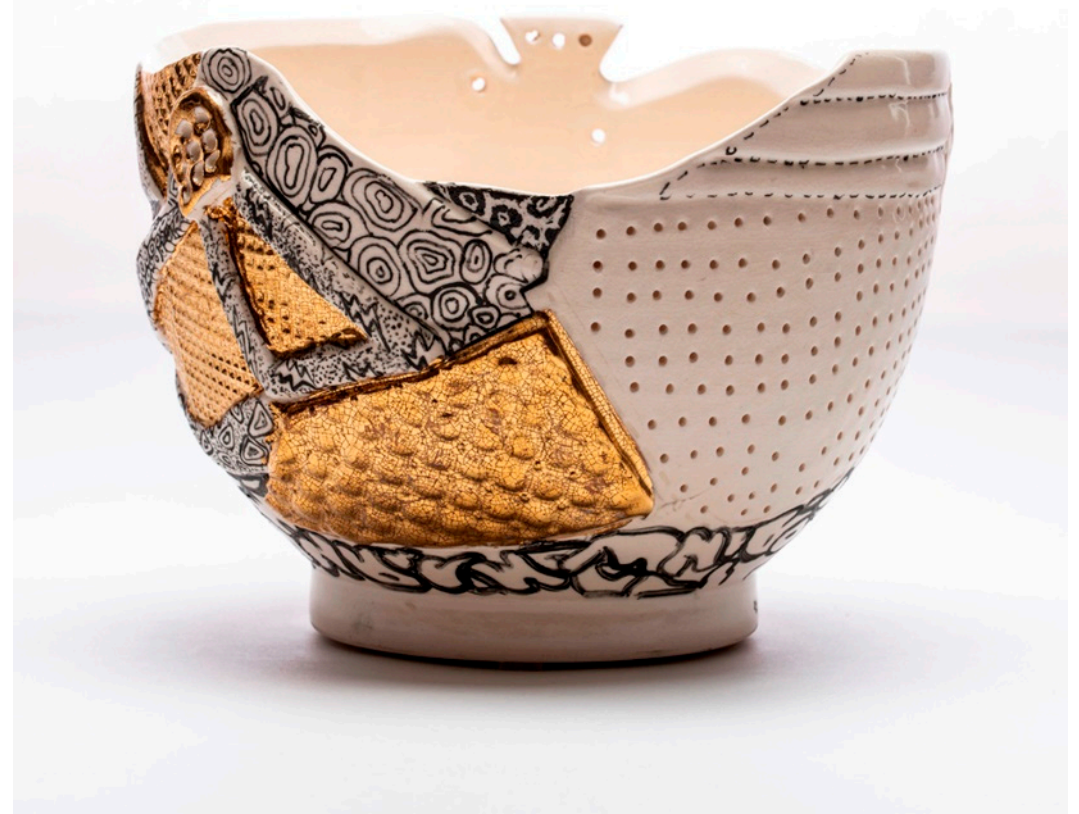

Figure 9. Stunting: Clean Joint, 2018, Porcelain, china paint, luster, $8 \times 10.5 \times 10.5 \mathrm{in}$. Image by KeneK Photography, courtesy of Wexler Gallery. 


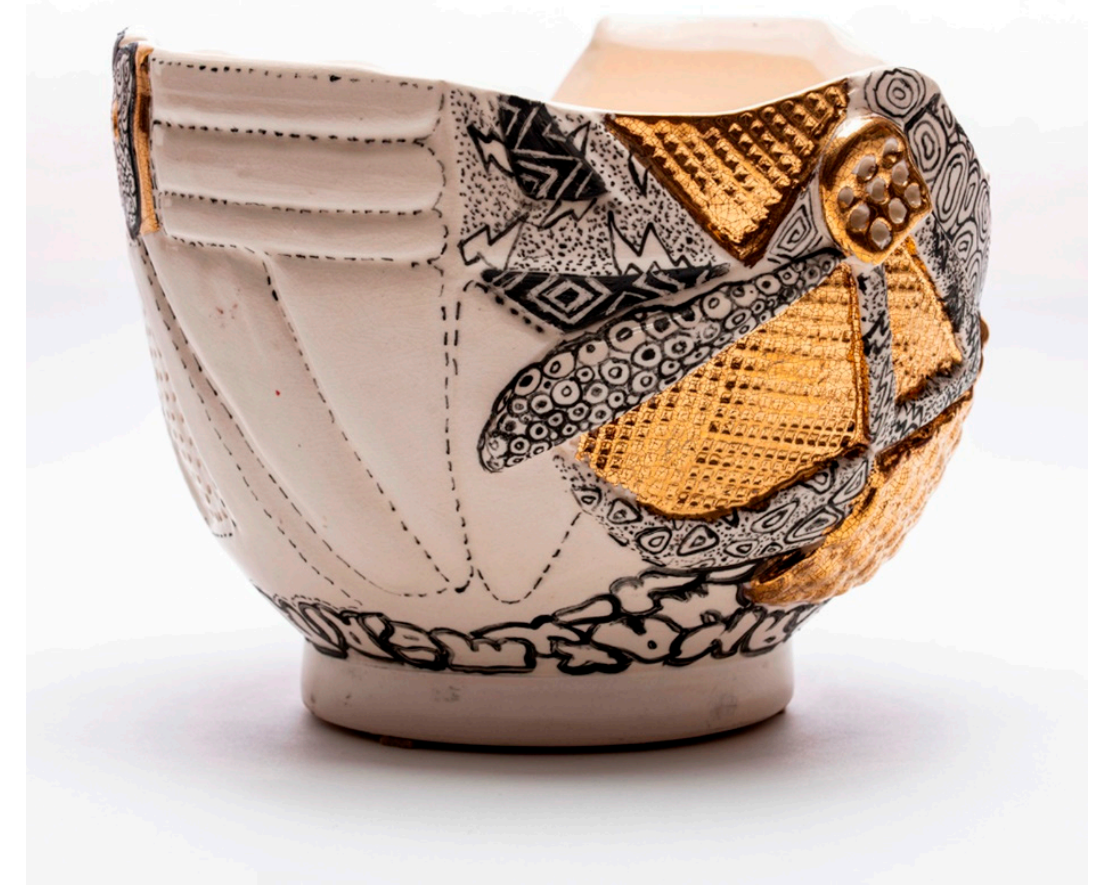

Figure 10. Stunting: Clean Joint, 2018, Porcelain, china paint, luster, $8 \times 10.5 \times 10.5$ in. Image by KeneK Photography, courtesy of Wexler Gallery.

While Lugo wields terms "ghetto potter" and "hip-hop artist through pottery" with ease and facility, the terms bear some complexity worthy of further consideration. Initially, Lugo speaks of hip-hop as identity in so much as it implies a person of color, of street or city living, and of a lower socioeconomic status or income level. When pushed to consider how hip-hop might be more than the agglomeration of these factors, Lugo refers to the aesthetic of good enough, being resourceful, or making do as factors of life on the streets. He asks that ceramics, a field that has concerns founded in issues of craft, including ability, finesse, and technical prowess, reconsiders how this disposition prioritizes a certain way of being and doing and asks us to reevaluate the reasons why someone might approach a material or problem differently. He explains that his way of doing and making might seem amateurish or nescient but that a slapdash approach has much to do with the circumstances and context that shaped who he is. Lugo explains, "I often make hasty decisions because I'm impatient; this impatience comes from the resourcefulness of growing up in a poor neighborhood where you often have to say, 'that's good enough.'" (Eds 2017, p. 11) Here, we are asked to reconsider how notions of work, painstaking, attention, time, care, repeated practice, and even the assumption of choice in production indicate a privileging of a kind of making and of one way of being over all others. This goes beyond familiar modernist (industrialized processes) and conceptual art examinations of work, craft, and production to a postmodern or culturally situated notion of production in which modes and approaches to making indicate a certain viewpoint, positionality, or subjectivity.

This suggests that fastidiousness, time, and refinement of skill and materials are kinds of privilege and indicate the dominant culture's ability to not only recreate power through a visible aesthetic, or its visuality (Mirzoeff 2011, p. 3), but it does so through its practices. He indicates that privilege, context, and culture have much to do with aesthetics and that a hip-hop aesthetic can offer a counter-narrative to existing hegemonic cultural practices and can stimulate new approaches to making allowing for new ideas, forms, practices, and viewpoints. Furthermore, a multiplicity of voices, viewpoints, and visual approaches stands to expand cultural modes of production, engendering creative possibilities through 
cultural intersections, hybridity, and deteritorializations of cultural and physical space (visualities and 3d forms) (Deleuze and Guattari 1980).

Lugo attributes African-inspired bright colors and bold patterns, like those found in the work of contemporary artist Yinka Shonibare, to a graffiti or hip-hop aesthetic. He explains that the patterns and bold colors that Shonibare (Art in the 21st Century Producer) uses in his fabrics and that are part of Lugo's conception of a hip-hop aesthetic as "life giving or life affirming". Lugo states, "A lot of these people certainly felt inferior," and their lives are often seen as insignificant or dispensable. He claims, "being able to put your name on something and claim ownership of it was really a reaction to [that] reality." And "if you're wanting to be seen, having your name highlighted in really bright colors makes a lot of sense." (R. Lugo, personal communication, 6 June 2018)

While many have questioned hip-hop's value as cultural expression (Castleman 2012), its most notorious visual form, graffiti, plays an important role in Lugo's work. Not only can its influence be seen in his ceramic work, but Lugo also has deep connections to the practice of graffiti. Lugo claims that he didn't have the opportunity to take art classes in school and that he came to be an artist through learning graffiti with Payne (Tony Cuco) (Shulman 2014, p. 48), and that while he was growing up, he practiced graffiti art with his cousins. "I started out tagging as a graffiti artist and I don't want to lose that. A lot of the things I do are gestural, but I also choose places to be tight", Lugo admits to Brown (2017). According to Brown (2017), Lugo still uses the same tag names on his ceramics that he used as a graffiti artist. The name Robske refers to himself, while Maz refers to his brother. He has since added a third name, Ask, which Brown (2017) claims "he conferred on his wife when the two began collaborating as artists" (p. 56).

Lugo's work marries a hip-hop or graffiti aesthetic with generic-yet-ornate white pottery meant to evoke a sense of classicism and investigate cultural assumptions of the superiority (and purity) of white wares. According to Essner (2016), Lugo "is equally influenced by the history of ceramics. Harnessing the aristocratic language of porcelain, traditional forms and ornament are his point of departure" (para. 5).

These nonspecific forms made of white clay refer to pots that are of a European or Asian ceramic vernacular but that don't refer specifically back to any exact form. They look like or mimic wares that would be found in well-to-do 18th century homes or as part of the elite gentility, yet we cannot specifically pinpoint the form to a type of pot like we can with Greek pottery, where a krater has a distinct form different from an amphora of a pyxis.

Furthermore, Lugo's teapot series that includes the work titled Celia Cruz-Basquiat Teapot is the physical marrying of hip-hop's visual and musical factions in what Brown (2017) terms "bonds of community" (p. 56). In this specific body of work, Lugo places images of notable people of color on the same vessel, which effectively creates connections and relationships between the two. In the Celia Cruz-Basquiat Teapot, 2016 (Figures 11 and 12), Celia Cruz, who was a Cuban-American singer known as "la reina de salsa" (the queen of salsa) (Pearlman 2008, para. 1), is paired with neo-expressionist painter Jean-Michel Basquiat. Lugo claims an affinity to Basquiat not only because they both use crowns (a practice and connection that Lugo didn't realize until discovering Basquiat well into his college career), but also because of Basquiat's connection to hip-hop and pop culture, his intelligent take on cultural relations, and his cultural heritage. Basquiat, an American artist of Haitian and Puerto Rican descent, used recurring symbols in his work, the most recognizable being the crown which he used, according to Rodrigues (2011), to denote "kings of cool" and which has been interpreted with the help of Hooks (1994) critical look at coolness as "referring not only to glory and power but also to dehumanization-to white and nonwhite males' willingness to "commit any unjust act that will lead them to the top." (p. 36) In another similar work, Incarceration Vase, Lugo places Frank Sinatra's mug shot, taken when being charged with adultery, on the same pot as civil rights leader Martin Luther King Jr. In each of these works, we are meant to draw connections and build meaning between the two images. 


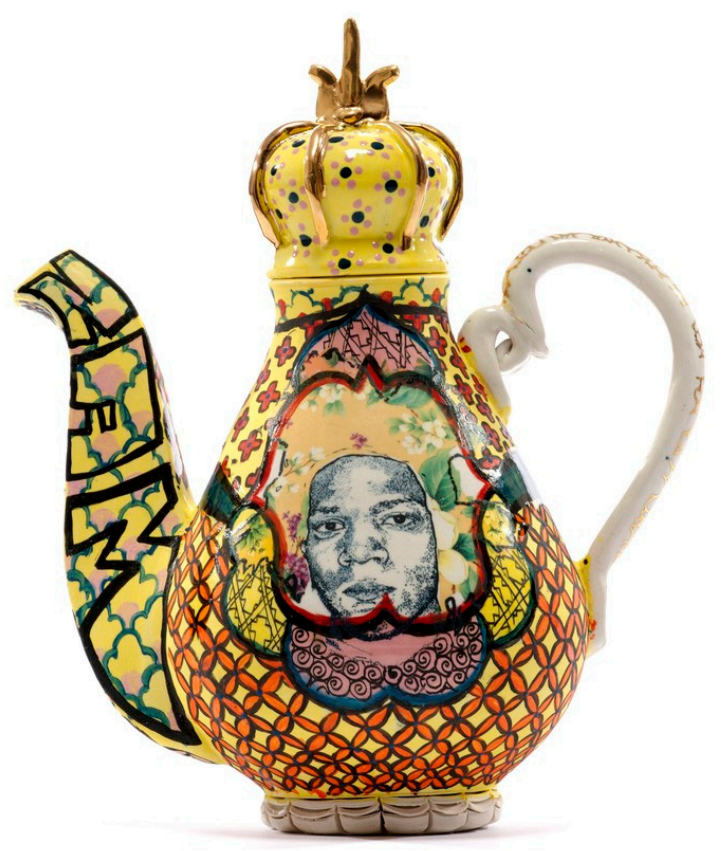

Figure 11. Basquiat/Celia Cruz Teapot, 2016 Porcelain, china paint, gold luster, $12 \times 10 \times 61 / 2$ in. Image by KeneK Photography, courtesy of Wexler Gallery.

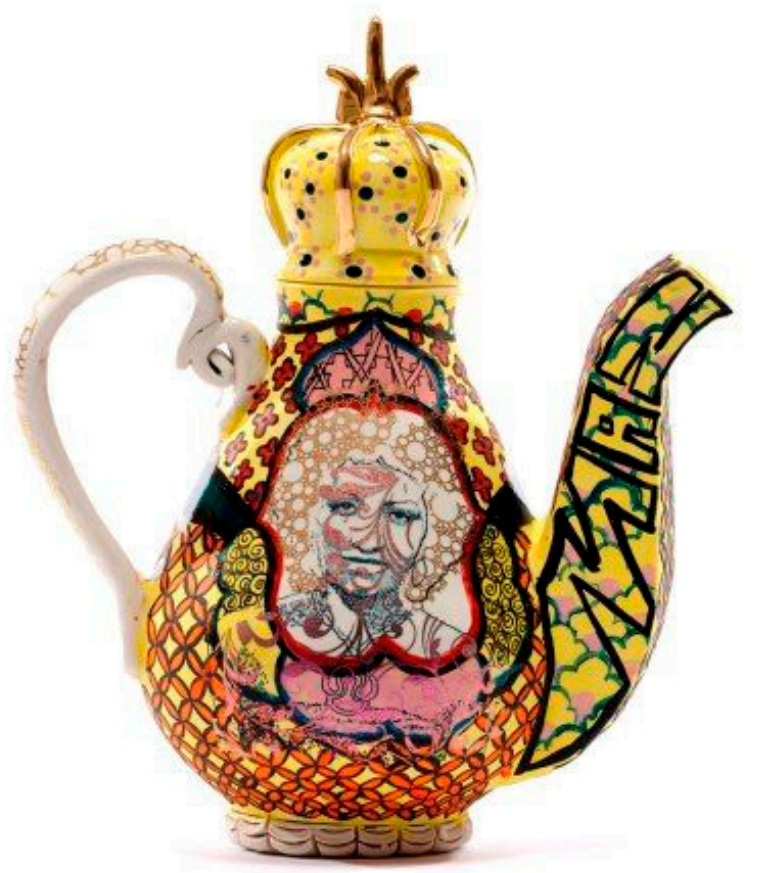

Figure 12. Basquiat/Celia Cruz Teapot, 2016 Porcelain, china paint, gold luster, $12 \times 10 \times 61 / 2$ in. Image by KeneK Photography, courtesy of Wexler Gallery.

\section{Hip-Hop, Identity Politics, and Identifying New Narratives}

Lugo explains that much of the reason that he juxtaposes the images and aesthetics of hip-hop onto white wares has much to do with a kind of reclaiming or reimagining of cultural and systemic power that has supported and propagated white hegemony and supremacy. Lugo (personal communication, 2018) explains, "The idea behind working in that way comes from this desire to put people in places where others don't think they belong or historically they haven't." (R. Lugo, personal communication, 6 June 2018) 
Lugo (2018) states, "And so I think some of the tenets of hip-hop are this idea of empowerment, of freedom, of ownership and creating our own identity separate from something that's been given to us by, you know, an Anglo history. And so, I think ceramics and the way that I'm working right now is just one facet to that." (R. Lugo, personal communication, 6 June 2018) Lugo (2018) continues, "Hip-hop is also a reaction to the Hispanic and black experience in the United States.... my work's a section of that and while it's made out of clay it's really just another way to tell that story." (R. Lugo, personal communication, 6 June 2018)

Brown (2017) sees the work as a statement of Lugo's identity, stating, "These are straightforward, even raw, declarations of identity." While there is much of Lugo in these works, there is also more to it than a mere singular statement of self. Indeed, Lugo makes works that feature his likeness (A Queen and I, 2018) (Figure 13) or that take on issues that he personally experiences (The Day my Belt Broke, 2013), but many more of his works deal in identity through engagement with concepts surrounding identity politics, questions of larger cultural inclusion, and an examination of systems of power that historically have prevented minority cultures from being in the position of power to tell their stories. Lugo's work reimagines these structures and not only tells his story but seeks to retell and reimagine larger cultural narratives, to create space for multiple voices, and to provide underprivileged and underrepresented peoples opportunities to be seen and to see through art experiences.

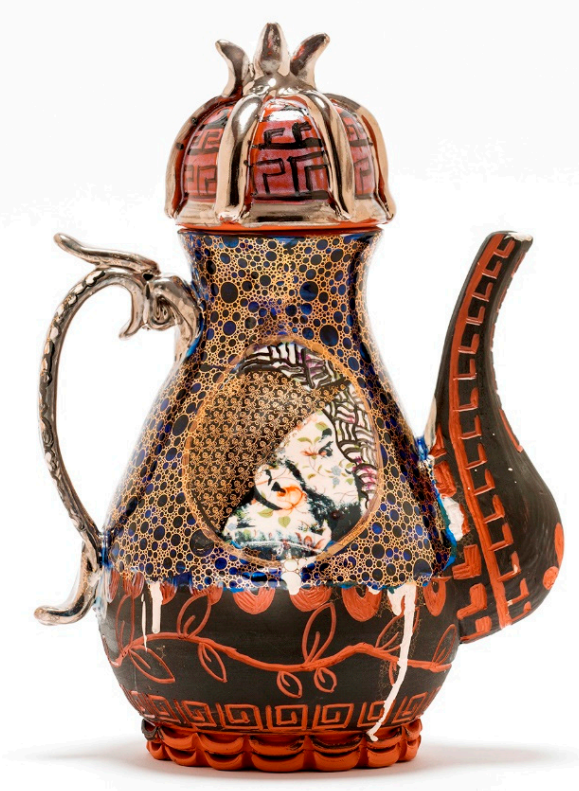

Figure 13. A Queen and I, 2018, Terra cotta, china paint, luster, $8 \times 6 \times 111 / 2$ in. Image by KeneK Photography, courtesy of Wexler Gallery.

In this way, Lugo's work is not only part of the hip-hop tradition through the aesthetic connections discussed earlier, but his work also follows the hip-hop tradition of social and political awareness and the telling of minority perspectives and retelling or recasting of dominant narratives through the perspective of young, black rappers, many of whom began as underground elements and gained public notoriety as through commercial acceptance. Certainly, Chuck D, front man for Public Enemy, is often quoted as describing rap music as "black CNN" (Neal 2012, p. 35). Speaking to the variety of voices coming out of hip-hop and black culture in general, Forman (2012) explains the inherent politics of hip-hop. He states:

These various points of conflict have an undeniably ideological character as well, especially when we consider the different values and perspectives that emerge around issues of 
race and class as well as such factors as age, gender, or locale. Indeed, it is sheer folly to conceive of hip-hop outside of an ideological analytical mindset, since the genre of rap music and the practices associated with B-boying and graffiti are each capable of articulating counter-hegemonic intentions and have done so throughout hip-hop's three decades of existence. (p. 11)

Given this, we might conclude that not only does Lugo's work embrace the vernacular of hip-hop, but that Lugo himself and the ideas that his ceramic work and that his leadership in the ceramics field embody are also hip-hop-meaning that they work to question, call attention to, and disrupt white hegemony. Admittedly, Lugo sees the leadership of Colin Kaepernick as part of the expanded field of hip-hop (to borrow an art term). As touched on earlier, Kaepernick launched onto the national political stage as a leader or symbol of the Black Lives Matter movement and as someone working to counter notions of white supremacy and question power structures and harmful practices of implicit bias. Lugo, also a leader for people of color within the ceramics field, embodies this expanded sense of hip-hop, creating a space for the voices of people of color, questioning and celebrating cultural differences, and expanding and stretching the field to include new ideas and new membership.

\section{Hip-Hop Practices beyond Pottery}

While we could characterize much of Lugo's work within the field of contemporary pottery, his practice is not singular. His work pushes beyond the neat and tidy confines that categorization in art conventionalizes. In addition to the widely well-received, remarkable, and layered ceramic works, Lugo engages in other forms of making. While Lugo's practice is varied, much of it engages with the patois of hip-hop. Of course, this is true of his early work as a graffiti artist, yet there are other practices that explore this vocabulary. Lugo engages with the performative aspect of his identity through the practice of spoken word poetry and rap, which he often employs during his artist talks. Lugo's 2015 NCECA Emerging Artist speech and the video performance work Ghetto is Re. source. ful exemplify this practice. This work seems somewhere between impromptu rap performance, rap video, confessional, and performance art. According to Essner (2016), Ghetto is Resourceful is "filmed in an abandoned lot near his (Lugo's) childhood home", "illustrates the ideas behind" his ceramic work, and "is a raw self-portrait". (para. 4) Here, Lugo uses the mediums of video, found objects, and spoken word in order to tell his story and illustrate the skillfulness and thrifty providence he attributes to growing up in the ghetto as a person of color.

In addition to this confessional and highly personal work, Lugo considers his civic, social, and educational work to be the most significant work that he does. In an interview granted as part of being named 2018 artist of the year, Lugo admits:

my other passion ... is introducing clay to every nook and cranny of the black and Hispanic communities, which don't often have access to clay ... what I really want to do is become irrelevant. I want so many people of color to become ceramic artists that I am just one grain of sand in a sunny beach where we all go play. (p. 9)

In addition to his work as an Assistant Professor of Ceramics at Tyler School of Art Temple University, Lugo has participated in an array of civic and educational programs. Lugo has participated in Bread KC and empty bowls while a student at the Kansas City Art Institute (Schulman 2014, p. 51). He has exhibited work and given a public talk with photographer Richard Ross in order to draw attention to the need for creative education as part of the juvenile justice system (Lugo 2013) and he has worked with The Clay Studio's clay mobile to help to bring ceramic-making opportunities to children in Philadelphia. In summer 2018, Lugo worked with 15-20 high school students through Artspace, New Haven's apprenticeship program, and he paired with The Clay Studio in a community project called “Making Place Matter" (Eds 2017, p. 10).

While the connection between these social, civic, political, and educational works and hip-hop may not be at first glance clearly related, hip-hop has a long history of this kind of involvement. 
While Kitwana (2012) describes a rift between the new Black youth culture of the hip-hop generation and the previous generation of civil rights and Black power based on public images of blackness, she explains a commonality between the two in their investment in community. Kitwana (2012) states:

Careful examination reveals that some rappers individually and collectively have consistently responded to issues important to this generation. The response may not have always been effective, or even politically correct, but they are the types of activities that have galvanized community-building efforts. The extent of the impact seems to be directly proportionate to the degree that such efforts work themselves into the fabric of hip-hop's cultural movement. (p. 458)

Even though Lugo's goal is equal access to opportunities to engage in rich materials and methods of expression like clay, and he claims that his pots and creative work are ancillary to the real work of creating opportunities for others, we might look at the pots themselves as operating in an activist manner. They seem to function in a similar way to rap from more socially-conscious or political rappers, like Public Enemy, KRS-One, Mos Def, Common, or Immortal Technique, whose work confronts political and social issues facing communities of color. Lugo's ceramics also do this work, yet his ceramics seem more palatable than other popular forms of minority expression, including political hip-hop, graffiti, and gangster rap. While there are some who oppose Lugo's politics and viewpoint, the larger ceramic field has, for the most part, embraced his work and the work seems not to have sparked the same controversies that hip-hop, gangster rap, and graffiti initially did and often still do today (Baldwin 2012; Castleman 2012; Chung 2015).

I submit that while Lugo's ceramic work does much to elevate minority culture and create a more inclusive art community, in doing so, it has shed some of the more difficult, objectionable, or confrontational parts of hip-hop practice. Specifically, the work refrains from the use of explicit imagery, language, and violence, and much of what is broached is done so through inference, allusion, metaphor, and portraiture rather than through brute depictions, head-on confrontation, or (threatening) anger. We might also conclude that Lugo's work contains a bit of what Kester (2013) refers to as the "ironic detachment" of contemporary work created in relationship to contemporary theory (p. 115). His work is cerebral and makes vernacular or textual connections between cultures and relies on art's recursive self-referentiality. Rather than engage with the messiness of cultural confrontation, it opts for what Kester (2011) calls "tactical withdrawal into the protected field of the text" (p. 45).

In order to elevate the conversation, stay above the fray, and avoid piling onto the media's negative stereotypes of African Americans and other people of color, Lugo's work omits many of the subversive or unsavory markers of hip-hop and graffiti, such as: Aggressive language, expletives, depictions of violence and murder, dysfunction of the black family, misogyny, and homophobia (Baldwin 2012, p. 230). Meanwhile, as part and parcel to its reception in the contemporary gallery scene, the work seems to encourage commodification, notions of personal property, and cultural elitism not unlike the very social, political, and cultural structures that Lugo's work examines. For instance, works from Lugo's Stunting series sell for between five thousand and seven and a half thousand dollars each. We might ask if those patrons and viewers who consume, support, and celebrate Black culture also fully consume, understand, and adopt Black social consciousness. We might also ask if the underrepresented and underprivileged whom Lugo seeks to provide opportunities to see and be seen through art making are indeed able to access, view, and benefit from his works.

It seems that Lugo adheres to and his main interest is in the notion expressed by First Lady Michelle Obama during the 2016 presidential campaign (Abcarian 2016) and reiterated in the name of one of his pots, When They Go Low We Go High, 2018 (Figures 14 and 15), although it is unclear if they refer to a "they" that Lugo distances himself from in order to cast off the less desirable aspects of minority culture or if "they" refers to those that would perpetuate and profit from misrepresentations of minority culture. 


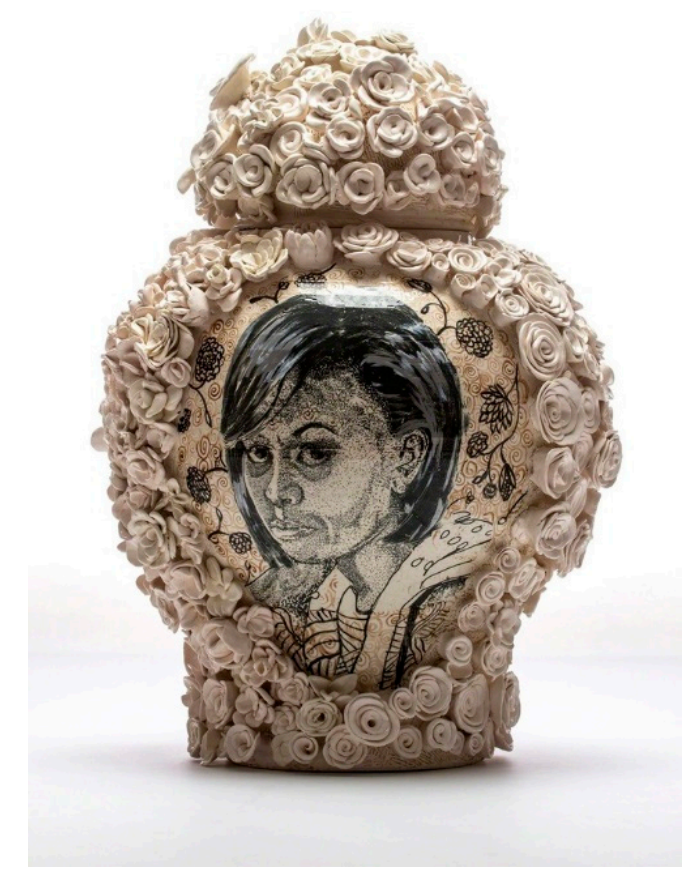

Figure 14. When They Go Low We Go High, 2018, Porcelain, China Paint, Luster, $25 \times 16 \times 14$ in. Image by KeneK Photography, courtesy of Wexler Gallery.

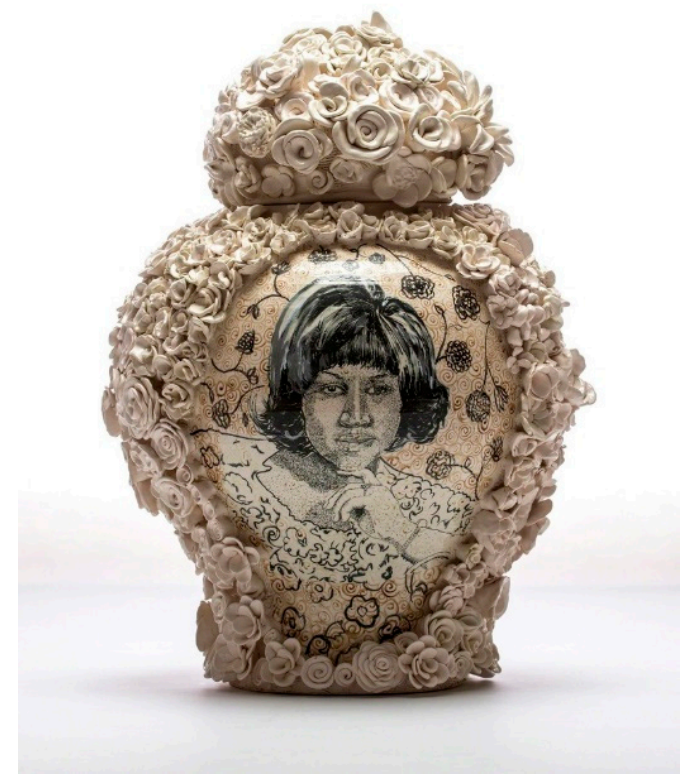

Figure 15. When They Go Low We Go High, 2018, Porcelain, China Paint, Luster, $25 \times 16 \times 14$ in. Image by KeneK Photography, courtesy of Wexler Gallery.

\section{Implications for Visual Culture and Art Education}

The ways that Lugo's work and practice intersect with hip-hop present many rich opportunities for critical discussion, involving a variety of visual cultures. Specifically, his work presents the opportunity to explore the field and cultural history of ceramics and to look more closely at hip-hop and minority culture and history. It presents the opportunity to explore the complexities and contradictions between traditional art making and the art market and activist, social consciousness-raising as part of the art world and hip-hop. On the whole, the study of Lugo's visual culture production and practices holds vast potential to engender meaningful, critical dialogue about the structures of art, culture, and power. 
Therefore, the study of Lugo's work would provide rich fodder for any multicultural or visual culture art education program that explores intersections of images, making, culture, power, race, and class.

Furthermore, Lugo is very much aware of art education's role in his practice and is quite interested in the ways that the theories of renowned art educator Olivia Gude intersect with his work. Gude is best known for her work with the Spiral Workshop at the University of Illinois at Chicago ${ }^{1}$ and for her conception of postmodern principles of art. Gude (2004) reinvents art education's traditional vernacular, the (Modernist) elements and principles of design, in order to account for new art making practices embraced by multicultural and contemporary artists. In particular, Lugo speaks about the way that such juxtaposition enlivens his work. He explains, "I think what's often jarring about what someone like me does is that you wouldn't expect hip-hop or graffiti to be placed on to pottery, or for those two worlds to exist in one." (R. Lugo, personal communication, 6 June 2018)

Likewise, Forman (2012) explains:

The evolution of hip-hop corresponds with cultural theorist Raymond Williams's observation that the process of "formal innovation" is gradual, and, while "residual" cultural practices from prior eras continue, new "emergent" cultural forms and practices may arise that challenge or disrupt the culture dominant. (p. 9)

Although not specifically mentioned by Lugo, his work involves many more of Gude's postmodern principles, which are "hybrids of the visual and conceptual" (Gude 2004, p. 8) and include appropriation, hybridity, layering, recontextualization, interaction of text and image, gazing, and representin' in addition to juxtaposition (Gude 2004, pp. 9-12). These principals not only describe contemporary art, but they are particularly postmodern in their ability to "participate in the unfolding of contemporary culture" and "to reflect on cultural issues related to self and society" (p. 8). In other words, the postmodern principles allow students to explore and deconstruct the visual as it creates and expresses meaning, culture, and power.

The notion that the visual, meaning that which is seen, creates meaning, culture, and power is known as visuality (Mirzoeff 2011) and visual culture art education is an art education that explores and deconstructs visuality, questions what it is to look and be the looker, or to be seen or represented, and deconstructs visual hierarchies in order to engender multiple knowledges, cultures, and ways of being. Visual culture art education also deals in how "we represent, make meaning, and communicate in the world around us (through the visual)" (Sturken and Cartwright 2004, p.1). Thus, much of what visual culture art education explores is also the expanded study of all things visual rather than the elitist study of the highest cultural standards, which often characterizes the study of fine art. Freedman (1997) claims "education should focus not only on the distribution of factual information, high culture, and students' own production, but also should include discussions of the popular visual culture that influences student knowledge." (p. 46) Thus, the study of Roberto Lugo's work not only offers an opportunity to engender discussions of popular visual culture, but his hip-hop aesthetic asks students to consider notions of visuality and to create and elevate new and multiple knowledges, cultures, and ways of being and making.

As an educator, Lugo's practice is somewhat different from established, school visual culture practices where students learn to read and speak back against the messages and meanings in images and other visual entities (Darts 2006; Duncum 2000, 2002; Freedman 1994; Freedman 2003; Stuhr and Ballengee-Morris 2001; Polaniecki 2006; Plummer-Rohloff 2006; Tavin 2003; Tavin and Anderson 2003; Taylor 2000). Unlike much of visual culture education, Lugo's artist educator practice takes on an amelioratory tone, meaning that much of what he does is to provide opportunities and experiences for people who previously would not have had the privilege. During Lugo's work with Artspace in New Haven, Connecticut Lugo facilitated the creation of ceramic rest in peace murals, in which

1 https://naea.digication.com/Spiral/Spiral_Workshop_Theme_Groups/published. 
twenty young adults paid homage to their heroes (Duff 2018). Here, Lugo's pedagogical approach is like that of an activist who provides opportunity and access and through them, his students are given a voice with which to speak back at dominant discourse. This approach provides one more possible pedagogical approach for empowering students to visually speak truth to power.

Roberto Lugo's work not only challenges and juxtaposes cultural practices, but the conversation and concepts that arise from the intersection of these cultural practices is healthy fodder for examinations of visual culture both inside and outside the art classroom. While Lugo's work aims to raise social consciousness through its content and form, its examination and employment of visual vernacular poses interesting questions that ultimately engender rich, critical dialogue. Classrooms that engage with the form, ideas, and concepts that Lugo employs stand to develop a more critical and culturally aware understanding of the possibilities and power of visual culture, art, and dialogue.

Funding: This research received no external funding.

Conflicts of Interest: The author declares no conflict of interest.

\section{References}

Abcarian, Robin. 2016. Michelle Obama's Stunning Convention Speech: When They Go Low We Go High. Los Angeles Times. July 25. Available online: www.latimes.com/politics/la-na-pol-michelle-speech-20160725snap-story.html\# (accessed on 30 September 2018).

Art in the 21st Century (Producer). 2009. Yinka Shonibare in "Transformation" Season 5 (DVD). Available online: https:/ / art21.org/watch/art-in-the-twenty-first-century / s5 / yinka-shonibare-mbe-intransformation-segment/ (accessed on 30 September 2018).

Baldwin, Davarian L. 2012. Black empires, white desire: The spatial politics of identity in the age of hip-hop. In That's the Joint: The Hip-Hop Studies Reader. Edited by Murray Forman and Mark Anthony Neal. New York: Routledge, pp. 435-37.

Bisson, Terry. 2009. John Brown: 150 years after Harpers Ferry. Monthly Review: An Independent Socialist Magazine 61: 37-39. [CrossRef]

Brown, Glen. R. 2006. Teaching ceramics history: Glen R. Brown gives some reflections on his experience teaching ceramics art history. Ceramics Technical 23: 37-42.

Brown, Glen. R. 2017. Roberto Lugo: Undermining indifference. Ceramics Monthly 46: 54-57.

Castleman, Craig. 2012. The politics of graffiti. In That's the Joint: The Hip-Hop Studies Reader. Edited by Murray Forman and Mark Anthony Neal. New York: Routledge, pp. 14-21.

Chung, Sheng Kuan. 2015. Media/visual literacy art education: Sexism in hip-hop music videos. Art Education 60: 33-38. [CrossRef]

Clark, Garth. 2007. Fortress ceramica: Answered prayers. Ceramic Art and Perception 70: 102-4.

Darts, David. 2006. Head Game ${ }^{\text {TM}}$ : Engaging popular vi\$ual@ulture. In Visual Culture in the Art Class: Case Studies. Edited by Paul Duncum. Reston: NAEA, pp. 99-108.

De Waal, Edmund. 2016. The White Road: Journey into Obsession. London: Picador.

Deleuze, Gilles, and Felix Guattari. 1980. A Thousand Plateaus: Capitalism and Schizophrenia. Minneapolis: University of Minnesta Press.

Duff, C. [Screen Name]. 2018. Roberto Lugo: Soil and Site [Video File]. Available online: https://vimeo.com/ 297334361 (accessed on 26 October 2018).

Duncum, Paul. 2000. Deconstructing media images of postmodern childhood. In Real World Readings in Art Education: Things Your Professors Never Told You. Edited by Dennis Fehr, Kris Fehr and Karen Keifer-Boyd. New York: Farmer Press, pp. 29-34.

Duncum, Paul. 2002. Visual culture art education: Why, what and how. International Journal of Art E Design Education 21: 14-23.

Eds. 2017. Roberto Lugo: Ceramic Artist of the Year. [Special issue Supplement Yearbook]. Ceramics Monthly, 8-12. Essner, Elizabeth. 2016. Roberto Lugo Is Changing the World One Teapot at a Time. Modern Magazine, March 29. Available online: http://modernmag.com/roberto-lugo-is-changing-the-world-one-teapot-at-a-time/ (accessed on 30 September 2018). 
Forman, Murray. 2012. Hip-hop ya don't stop: Hip-hop and historiography. In That's the Joint: The Hip-Hop Studies Reader. Edited by Murray Forman and Mark Anthony Neal. New York: Routledge, pp. 9-12.

Freedman, Kerry. 1994. Interpreting gender and visual culture in art classrooms. Studies in Art Education 35: 157-70. [CrossRef]

Freedman, Kerry. 1997. Critiquing the media: Art knowledge inside and outside of school. Art Education 50: 46-51. [CrossRef]

Freedman, Kerry. 2003. Teaching Visual Culture. New York: Teachers College Press.

Gregory, Sean. 2017. Colin Kaepernick. Time 190: 100-3.

Gude, Olivia. 2004. Postmodern principles: In search of a 21st century art education. Art Education 57: 6-14. [CrossRef]

Gupta Wiggers, Namita. 2013. Navigating Whiteout Conditions: 2013 Distinguished Lecture. Paper presented at 2013 NCECA Conference, Houston, TX, USA, March 20-23.

Hooks, Bell. 1994. Outlaw Culture. New York: Routledge.

Kester, Grant. 2011. Temporary coalitions, mobilized communities, and dialogue as art. In What We Made: Conversations on Art and Social Cooperation. Edited by Tom Finkelpearl. Durham: Duke University Press, pp. 114-31.

Kester, Grant. 2013. The One and the Many: Contemporary Collaborative Art in a Global Context. Durham: Duke University Press.

Kitwana, Bakari. 2012. The challenge of rap much from cultural movement to political power. In That's the Joint: The Hip-Hop Studies Reader. Edited by Murray Forman and Mark Anthony Neal. New York: Routledge, pp. 452-61.

La Force, Thessaly. 2015. The European Obsession with Porcelain. The New Yorker. November 11. Available online: https: / www.newyorker.com/books/page-turner/the-european-obsession-with-porcelain/amp (accessed on 30 September 2018).

Lopez, Alfr. 2005. Introduction: Whiteness after empire. In Post-Colonial Whiteness: A Critical Reader on Race and Empire. Edited by Alfred Lopez. Albany: SUNY Press, pp. 1-30.

Lugo, Roberto. n.d. Statement. Available online: http:/ / robertolugostudio.com/ (accessed on 30 September 2018). Mirzoeff, Nicholas. 2011. The Right to Look. Durham: Duke University Press.

Neal, Mark Anthony. 2012. "The message": Rap, politics, and resistance. In That's the Joint: The Hip-Hop Studies Reader. Edited by Murray Forman and Mark Anthony Neal. New York: Routledge, pp. 435-37.

Pearlman, Ellen. 2008. Azucar! Celia: The Life and Music of Celia Cruz at the New World Theater. Brooklyn Rail. March 7. Available online: https://brooklynrail.org/2008/03/music/azcar-celia-the-life-and-music-ofcelia-cruz-at-the-new-world-theater (accessed on 30 September 2018).

Plummer-Rohloff, Rebecca. 2006. Beyond the circus: Grounding a visual culture pedagogy. In Visual Culture in the Art Class: Case Studies. Edited by Paul Duncum. Reston: NAEA, pp. 65-71.

Polaniecki, Sherri. 2006. Teaching through TV: Transformative encounters with constructed reality. In Visual Culture in the Art Class: Case Studies. Edited by Paul Duncum. Reston: NAEA, pp. 39-46.

Rodrigues, Laurie. 2011. SAMO@ as an escape clause: Jean-Michel Basquiat's engagement with commodified American Africanism. Journal of American Studies 45: 227-43. [CrossRef]

Schulman, Blair. 2014. Roberto Lugo: Not fearing the message. Ceramic Art and Perception 98: 48-51.

Stapleton, Alex (Producer), Thibuat de Longeville, and Lisa Leone (Directors). 2005. Just for Kicks [Motion Picture]. New York: CAID Productions Program 33.

Stuhr, Patricia, and Christine Ballengee-Morris. 2001. Multicultural art and visual culture in a changing world. Art Education 54: 6-13.

Sturken, Marita, and Lisa Cartwright. 2004. Practices of Looking: An Introduction to Visual Culture. New York: Oxford University Press.

Tavin, Kevin. 2003. Wrestling with angels, searching for ghosts: Toward a critical pedagogy of visual culture. Studies in Art Education 44: 197-213. [CrossRef] 
Tavin, Kevin, and David Anderson. 2003. Teaching (popular) visual culture: Deconstructing Disney in the elementary art classroom. Art Education 56: 21-35.

Taylor, Pamela. 2000. Madonna and hypertext: Liberatory learning in art education. Studies in Art Education 41: 376-89. [CrossRef] 